D) Check for updates

Cite this as: $B M J 2021 ; 372: n 753$ http://dx.doi.org/10.1136/bmj.n753

Published: 19 March 2021

\section{Domestic violence during the pandemic}

In this editorial by Gene Feder and colleagues (BMJ 2021;372:n722, doi:) the affiliations for Poonam Rishal were incorrect. She is a co-investigator at Dhulikhel Hospital, Kathmandu University Hospital. The online version has been corrected. 